Transactions of the Royal Asiatic Society of Great Britain and Ireland http://journals.cambridge.org/TRA

Additional services for Transactions of the Royal Asiatic Society of Great Britain and Ireland:

Email alerts: Click here

Subscriptions: Click here

Commercial reprints: Click here

\title{
IX. On Hindu Courts of Justice
}

Henry Thomas Colebrooke

Transactions of the Royal Asiatic Society of Great Britain and Ireland / Volume 2 / Issue 01 / March 1830, pp 166 - 196
DOI: 10.1017/S095047370000135X, Published online: 19 November 2009

Link to this article: http://journals.cambridge.org/abstract S095047370000135X

How to cite this article:
Henry Thomas Colebrooke (1830). IX. On Hindu Courts of Justice. Transactions of the Royal Asiatic Society of Great Britain and Ireland, 2, pp 166-196 doi:10.1017/S095047370000135X

Request Permissions : Click here 
IX. On Hindu Courts of Justice. By HENRY Thomas COLEBRooke, Esq.,
Director R.A.S.

Read May 24, 1828.

The composition of an Indian court of justice, conformably with the ancient Hindu institutions, being very imperfectly understood, and many erroneous notions having become prevalent on this subject, it appears to deserve a more full investigation than it has yet undergone; and, with this view, I submit to the Society the result of a careful perusal of original authorities of Hindu law relating to that point.

The following is an abstract,* from very ample disquisitions, contained in treatises of Indian jurisprudence.

An assembly for the administration of justice is of various sorts : either stationary, being held in the town or village; or moveable, being held in field or forest; or it is a tribunal superintended by the chief judge appointed by the sovereign, and entrusted with the royal seal to empower him to summon parties; or it is a court held before the sovereign in person. The two first of these are constituted at the request of parties, who solicit congnizance and determination of their differences; they are not established by operation of law, nor by the act of the king, but by voluntary consent. The two last are courts of judicature, established by the sovereign's authority : such a court is resorted to for relief as occasions occur, and not, as the first-mentioned, constituted merely for the particular purpose.

To accommodate or determine a dispute between contending parties, the heads of the family, or the chieis of the society, or the inhabitants of the town or village, select a referee approved by both parties.

Among persons who roam the forest, an assembly for terminating litigation is to be held in the wilderness; anong those who belong to an army, in the camp; and among merchants and artisans, in their societies.

* A short extrace fom this treatise was communicated to Mr.H. St. George Tucker, fu insertion in the Appendix to his work on the financial state of the East-India Company. 
Places of resort for redress are:

1st. The court of the sovereign, who is assisted by learned Bráhmans as assessors. It is ambulatory, being held where the king abides or sojourns.

2d. The tribunal of the chief judge ("Prád viváca," or "Dilarmádhy" acsha") appointed by the sovereign, and sitting with three or more assessors, not exceeding seven. This is a stationary court, being held at an appointed place.

3d. Inferior judges, appointed by the sovereign's authority, for local jurisdictions. From their decisions an appeal lies to the court of the chief judge, and thence to the raja or king in person.

The gradations in arbitration are also three:

1st. Assemblies of townsmen, or meetings of persons belonging to various tribes, and following different professions, but inhabiting the same place.

\&d. Companies of traders or artisans; conventions of persons belonging to different tribes, but subsisting by the practice of the same profession.

3d. Meetings of kinsmen, or assemblages of relations connected by consanguinity.

The technical terms in the Hindu for these three gradations of assemblies are, 1st. Puga; 2d. Sréni; 3d. Cula.

Their decisions or awards are subject to revision; an unsatisfactory determination of the "Cula" or family, is revised by the "Sréni," or company, as less liable to suspicion of partiality than the kindred; and an unsatisfactory decision of fellow-artisans is revised by the "Puga," or assembly of cohabitants, who are still less to be suspected of partiality. From the award of the "Puga," or assembly, an appeal lies, according to the statutes of Hindu law, to the tribunal of the "Prád-iiváca," or judge; and, finally, to the court of the Raja, or sovereign prince.

The "Puga," "Sréni," and "Clila," are different degrees of arbitration, which, as is apparent, is not in the nature either of a jury or of a rustic tribunal, with which they have been assinilated; but merely a system of arbitration, subordinate to regularly constituted tribunals or courts of justice.

I now proceed to the more detailed consideration of the composition of such courts.

In several passages of Hindu law books the members of the judicature are enumerated, but not without some discrepancy : one authority specifying so many as ten; others eight, but in some instances, nevertheless, noticing a greater number. The difference, however, is not material. 
That enumeration concerns the sovereign court, wherein the king personally presides. The composition of subordinate tribunals, with respect to its members and attendants and officers, has not been particularized; nor are there any directions found concerning the manner in which the business of inferior courts is to he conducted, or the sittings of arbitrators. No doubt the analogy of the sovereign court would be followed, so far as applicable; and the composition of the highest tribunal would be the type or model for the construction of a subordinate one.

A court of judicature is, in the passages which have been adverted to, likened to a body furnished with limbs; and the similitude of the members of the one and limbs of the other is followed out to a puerile minuteness. Without regard, however, to this solemn trifling, it may be observed, that the members enumerated are: first, the king or sovereign prince; next, the chief judge, or superintendent appointed by him; afterwards the assessors or puisne judges, considered in the aggregate as one member, though their number ought to be three, five, or seven. The written law is to be had for reference or consultation, and is mentioned as one member; gold and fire are also to be in readiness, for use in the administration of oaths, and are in like manner noticed as members; as is also water, provided for refreshment. The principal officers of the court, namely, the accountant, the scribe, and the sequestrator, complete the formal enumeration. But to these must be added, other officers and attendants of the court, as the summoner and the moderator; likewise the king's domestic priest or spiritual counsellor, and his ministers of state or temporal advisers; and also the audience or by-standers, comprehending qualified persons, any one of whom may interpose in the capacity of an amicus curice; and persons in attendance to keep order and prevent the intrusion of the populace.

By the Hindu institutes, the administration of justice, civil and criminal, is among the chief functions of the Raja or sovereign; not arbitrarily, according to his mere will and pleasure; but conformably with fixed laws recorded by ancient sages, and agreeable to the established custom of the country.

He will naturally need the assistance of learned persons conversant with those laws and usages, and competent to the application of them in particular and individual cases. There is need likewise of attendants and officers to conduct the process and execute the adjudications of the tribunal. The number, functions, and powers of those advisers and attendants, as 
prescribed by law, form the legal constitution of a Hindu sovereign court.

It is a topic considered and discussed in every general treatise of Indian forensic law : there is no occasion, therefore, for premising a disquisition on the authorities to which reference will be made.

$\S$ 1. The sovereign Prince.

The Hindu sovereign in person hears litigant parties to redress injuries and decide their contests; or he devolves that office on a chief judge, whose duty it is to assist him when present, and to preside in his stead when absent. The right of personal superintendance is in strictness confined to the regular royal tribe of cshatriya, or to the brálman'a invested with sovereignty: one of an inferior class, whether the third or the fourth caste, or a mixed tribe, is not qualified to assume personal cognizance of causes, but is by law required to depute a judge to officiate in his stead. On this point, however, commentators of the law differ; some maintaining the competency of every sovereign, whatever be his tribe, for the personal exercise of judicial authority.

It is the sovereign on whom the duty of administering justice is incumbent. The chief judge, attendants, and officers, are only assistant in the trial of causes, like a stipendiary priest in the celebration of religious rites; and they possess no proper nor original jurisdiction. It is a positive obligation on him; and the attendance of the rest is not indispensable. The spiritual reward of a due administration of law, and the offence of its omission, concern him alone.*

Composure and sedateness of demeanour, with simplicity of dress and ornament, are enjoined, lest the suitors of the court be overawed and confounded. A sitting posture facing the east is directed for a spiritual purpose ; yet a trivial case may be heard by the prince standing; but he should not be walking to and fro, nor lying down, nor reclining. He holds out bis right arm, wearing his mantle in the manner of a scarf, as is usual in an assembly of brálman'as, and having his hand free to make signs when there may be occasion so to do.

\section{\$. The chief Judge.}

The chief judge assists the prince when present, or presides in court

VoL. II.

* Sm. Chandricá, \&sc. 
when he is absent. The proper title of this high officer is Pràd-viváca, which signifies ' interrogator and discriminative pronouncer.' He questions the parties; investigates the case ; distinguishes right and wrong; awards trial; and pronounces judgment. All this is implied in the title of his office. Another designation is Dharmádhyacsha, superintendent of justice. It occurs in the rubrick and colophon of divers treatises on law, as the author's official designation, especially in the works of HELÁyudHa.

The chief judge should be a brálman'a, observant of the duties of his tribe; conversant with the law in all its branches; skilled in logic and other sciences; acquainted with scripture and jurisprudence; and versed in holy literature, possessing conciliatory qualities, with many attainments. He should be gentle, not austere; deliberate, patient, and placid, yet firm; virtuous, wise, diligent, cheerful, impartial and disinterested; and, above all, sincere.

But, if a brámman'a duly qualified cannot be found, a man of the military class, or one of the commercial tribe (that is, a cshatriya, or a vaisya), who is conversant with jurisprudence, may be appointed chief judge: but not a s'ídra, on any account, whatever be his knowledge and qualifications. This prohibition concerns spiritual consequences regarding the king's fortunes; it does not affect the validity of the s'ídra's judicial acts.

\section{§3. The Assessors.}

The assessors of the court, appointed by the sovereign to assist the chief judge with their advice, or himself when presiding there in person, are three, five, or seven, not fewer than the less, nor more than the greater number mentioned; an uneven number being required, that, in case of disagreement, the opinions and votes of the majority may prevail, supposing their capacity and qualifications equal.

They should be bráhman'as, versed in sacred and profine literature, conversant with jurisprudence, habitually veracious, and strictly impartial towards friend and foe; being honest, disinterested, and opulent; incorriptible, attentive to their duties, and devoid of wrath and avarice, and uninfluenced by other passions.

If brálman'as duly qualified cannot be selected, cshatriyas or cais'yas may be nominated; but not a s'údra by any means. The judicial acts of an incompetent or disqualified person are void, though they chance to be conformable with the law. In the instance of the chief judge, however, 
the s'údra's act is not void; neither should it be deemed so in the case of the assessor.

\section{\$ 4. The Audience.}

Writers on Hindu law reckon the audience as a component part of a court of justice; for a bystander may interpose with his advice, as the amicus curia does in an European court.

This part of the audience consists of persons qualified to sit in court as assessors, being learned brálman'as, conversant with law; not appointed to be assessors, but attending the court of their own accord, or upon their own affairs. Their interposition is not equally incumbent as it is on the assessors; nor is it called for, unless they possess such qualifications.

A further part of the audience consists of persons attending the court to maintain order, and prevent the intrusion of the populace. They should be vais'yas, that is, persons of the third tribe, either merchants or husbandmen.

\section{5. The Domestic Priest, or Spiritual Adriser.}

The king's domestic priest is regularly a member of the sovereign court of judicature. His nomination is specifically for the one object, as much as for the other : and it is his incumbent duty to check and restrain the king. from wrong proceedings, no less in judicial than in religious matters. The nomination of one such priest being sufficient, no more than one is to be appointed. He should be a brálman'a, versed in science, faithful, disinterested, diligent and veracious.

\section{$\oint 6$. Ministers of State.}

The ministers of state attendant on the king, are reckoned among the component members of the sovereign court; or, the chief judge and the assessors or councillors, being selected from among the king's ministers and public servants, attend in those capacities, and are strictly members of the court.

\section{\$7. Officers of the Court.}

The proper subordinate officers of the court are five, riz.

1. Accountant;

2. Scribe;

3. Keeper of claims and enforcer of judgments ;

4. Messenger, or summoner of parties and witnesses;

5. Moderator of the court.

$$
\mathrm{Z} 2
$$


1. The requisite qualifications of the accountant are skill in computation, and a thorough acquaintance with every branch of mathematical knowledge; including astronomy (and even astrology), grammar, and other sciences, as well as sacred studies, and familiar knowledge of various modes of writing. He must be pure in conduct, and clearly deserving of trust.

2. The like qualifications are required of the scribe. His diction must be unambiguous; his hand-writing fair : he must be honest, placid, disinterested, and veracious.

Both these officers should be of a regenerate tribe.

3. The enforcer of judgment, and guardian of things claimed, may be a s'ídra. He should be one who has been uniformly employed in the king's service; firm in conduct, but strictly obedient to the judges of the court. His functions are, the custody of things in dispute during the pendency of the cause, and the giving effect to the court's judgment.

4. The messenger, or king's own officer, is one who has been long in his service, but is placed by him under the control of the judges, for the duty of summoning parties, holding them in custody, and seeking and calling their witnesses.

5. Another officer is noticed, under the designation of moderator of the court, but with no other functions assigned to him besides the delivery of discourses on morality for the edification of the parties in suits, the judges, and the officers of the court.

\section{§ 8. Conduct of Judges.}

Passages relative to the conduct of judges, their functions and duties, are very numerous in the institutes of Hindu law. These may not be without interest, collected and exhibited together for reciprocal illustration.

It will be obvious, from the frequent notice of the direct part taken by the sovereign in the administration of justice, and the manner in which this topic is weighed upon, that both when the institutes were written in the names of ancient sages, and when compilations were made from them by later authors, whose names are attached to works received as authority in divers countrics of India, the Hindu sovereigns were accustomed to preside in their own tribunals, and take a personal and active share in the discharge of judicial duties.

'The obligation of impartial justice incumbent on the sovereign and the judges, is earnestly inculcated, in language forcible and impressive. Careful 
investigation, a candid avowal of opinion, and strenuous remonstrance against unjust decisions, are strongly enjoined; and it appears from the whole tenour of numerous passages, that the monarch presiding in person determines the causes on his own responsibility. The assessors of the court merely offer advice, but have no voice or vote in the decision.

\section{S9. Punishment of iniquitous Judges.}

Iniquitous judges are punishable by fine, exile, and confiscation, for partiality, corruption, and collusion.

The fine is rated at twice the amount of the penalty to which the party cast would be liable; or, according to a different inference from the same law, twice the value of the thing litigated: but where this is not appreciable, the prescribed punishment is confiscation of property. This, however, is a controverted point; and the first-mentioned construction is the prevalent one. Confiscation extends to the whole property of the offender; and is awarded in a case of bribery; as is banishment also.

If the judge's iniquity be not discovered until after judgment has been passed, he is held bound in amends to make good to the aggrieved party the whole amount of his loss. Whether the cause shall be reheard, is a controverted point: one authority requiring revision of the judgment, and another directing that it shall not be disturbed, but amends made to the aggrieved party. This difference is grounded on a variation in the reading. of the same text of law.

\section{\$10. Court-House.}

Minute directions are given concerning the situation and aspect of the court-house, and the decorations of the apartment in which the court is held. It will be sufficient to cite authorities on these points, without going into a discussion of unimportant questions arising out of them. It matters little whether the court-room should be an apartment of the royal palace or a separate edifice: nor does it much signify what are the proper and auspicious dimensions of a building designed for this purpose, according to Hindu notions of symmetry. The east is the prescribed aspect, whether the house be a distinct one, or contiguous to the palace.

$\checkmark 11$. Time and mode of Sitting.

There is something curious, or approaching to it, as descriptive of ancient manners, yet not differing much from the habits of modern Hindu princes, in the minute directions given concerning the time when the courts should sit, 
riz. the forenoon, as most convenient; the hour at which the king should take his seat after early religious observances and ordinary preparations of the morning; the manner in which the members of the court are dis: tributed, the king facing the east, the judges on the right, the scribe on his left, and the accountant facing him ; and likewise concerning inauspicious days, on which courts should not assemble.

To this brief summary I annex a copious collection of passages relative to all points which have been here touched upon. It will be found to be full and sufficient on the whole subject, amply explaining the constitution of a Hindu sovereign court, its jurisdiction, original and appellate, and that of subordinate courts, and arbitration in several gradations. The topic is not without importance for its political bearing, as well as for illustration of Hindu manners.

\section{A P P EN D I X.}

\section{$\S 1$. Resort for Redress of Wrongs.}

"BHR̆Gu* ordained ten or else five places for the trial of causes, where litigant parties, involved in controversies, may obtain decisions.

"The frequenters of forests should cause their differences to be determined by men of their own order; members of a society, by persons belonging to that society; people appertaining to an army, by such as belong to the army; and the inhabitants of town [and country], $\uparrow$ likewise by residents in both.

" Let the heads of the family, or the chiefs of the society, or the inhabitants of the city, or of the village, select an umpire, approved by both parties.

"The village, the townsmen, an assemblage of families, associations of artisans, and a scholar in the four sciences, persons belonging to the same class, allied families, heads of the family, constituted judges, and the king, [are the several judicatories.t]

"Among persons who roam the forest, a court should be held in the wilderness; among those who belong to an army, in the camp; and among merchants, in their own societies. $\$$

" ' Men of their own order,' are persons abiding in the forest. From the term ' likewise,' which occurs in the text, it appears that they who reside in a town or village and

\footnotetext{
* Or Menu, according to the Smriti Chandrica.

† Mádh.

f Bhrgugu, cited in $S m$. Ch. and Mádh.

$\oint$ Vrǐhaspati, cited in Calpataru; Cátyáyana, in Vyavahára Chintáman'i.
} 
in the forest or wilderness, should cause their disputes to be adjusted by residents in both: that is, by persons abiding in the village and the forest [for they are conversant with disputes incident to both.*] The heads of the family are the chief persons among the kindred. The chiefs of the society are the leaders of a company assembled in a village, or on a pilgrimage, and so forth. The city signifies the principal town; the village, one inferior thereto: thus there is a distinction between the inhabitants of a city and of a village. The umpire, selected by the family, completes the number of five resorts. They are suited to particular descriptions of persons, as foresters, \&c. $\dagger$

"An assembly is of four sorts: stationary, moveable, graced by the signet, and governed by the institutes of law; the judges or arbitrators are as various. A stationary court meets in the town or village; a moveable one is assembled in the forest; one graced by the signet is superintended by the chief judge; one governed by the institutes of law is held before the king. $f$

"The five first places of reference are adapted to particular descriptions of persons, as foresters and the rest. If a dispute arise among persons dwelling within the bounds of a village, it is determined by the inhabitants of the adjoining villages. The heads of families, the chiefs of societies, and the inhabitants of towns and villages, select an umpire approved by both plaintiff and defendant.

"The village and the rest are ten resorts common to all. The village intends people dwelling together in the manner of a hamlet. Townsmen are the whole of the inhabi-

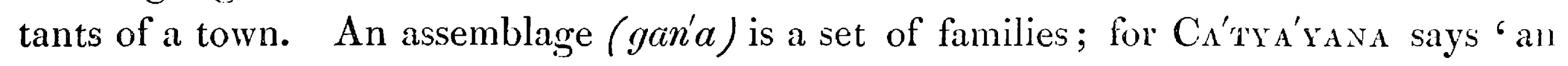
assemblage of families is termed gan'a. Associations denote washermen and the rest of eighteen low tribes. A scholar in the four sciences is a man conversant in logic and the rest of four requisite branches of knowledge. The conjunctive particle, which occurs in this place, indicates the association of such scholar with other learned persons; for Pitam'ahn forbids the exposition of the law by one individual, however learned. Persons belonging to the same class (varga) are such as appertain to the same assemblage,

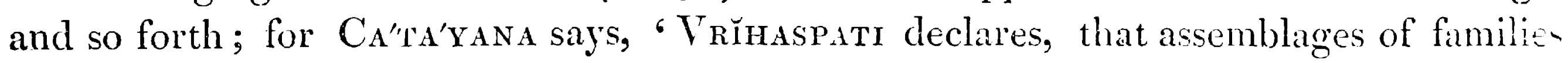
and societies of heretics, companies of armed men, unions of low tribes, as well as other associated persons, are termed varga.' The authority of VRĭnsspats is cited to show, that the term was already known in this acceptation. A company of armed men is is party of persons variously armed; for it is so explained by the same author. Familie: import such as are related to the plaintiff or to the defendant within the degree of sagótra. Heads of families are elders sprung of the same lin with the plaintiff and defendant. Constituted judges are the chief judge with three assessors. The linis, assisted by brálman'as, Rc. is last.

"An assembly, which is held in the forest or other of three situations [first mentionel] is moveable; for, in general, it is suited to travelling. Among inhabitant of both town and country and other specified situations it is stationary, for it is not adapted to chans:

* Viramitródaya. $\quad+$ Múdh. in Madhavíya.

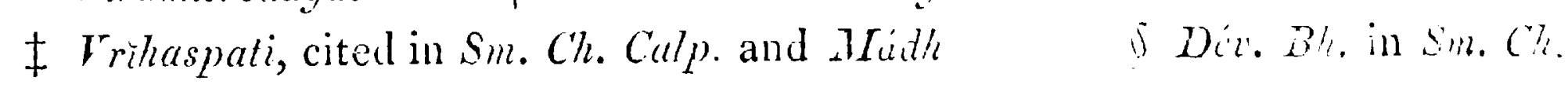


of place. One held at an appointed spot is graced by the signet; for it is attended by the superintendent or other officer holding the seal. But at the king's residence the court is one governed by the law; for it is precisely guided by the sacred institutes. This distribution of courts is shewn by the same author. The superintendent is the chief judge; for he is appointed by the king to try causes, and the royal seal is entrusted to him, that he may be enabled to summon defendants. This is implied in the text. The stationary and the moveable assemblies are specially constituted at the request of parties soliciting the meeting, with presents and other means of inducing consent; for such tribunals are not established by the mere operation of law, nor by the spontaneous act of the king. But a court graced by the signet, and one governed by the law, are established by the king of his own authority; therefore, to obtain a decision the court is resorted to, not constituted for the special purpose. The king's court, governed by law, is superior to all the rest.*

\section{§2. Jurisdiction original and appellate.}

" Judges appointed by the king, assemblies [of townsmen], companies [of artisans], and meetings [of kindred], must be understood to be superior, the one to the other, in order as here enumerated, for the decision of law-suits among men. $\dagger$

“ Meetings [of kindred], companies [of artisans], assemblies [of co-habitants], an appointed judge, and the king himself, are resorts for the trial of law-suits; and, among these, the last in order is superior to the preceding. $\neq$

" Persons who have been fully appointed by the king, the kindred of the parties, fellow-artisans, co-habitants, and others, may decide law-suits among men, excepting causes concerning violent crimes. Meetings of kinsmen, companies of artisans, assemblies of co-habitants, and courts of justice, are declared to be judicatories, to which he, against whom judgment is given, may successively resort. A cause, which has not been thoroughly investigated by the kinsmen, must be tried by persons of the same profession with the parties; one, which has not been well adjudged by fellow-artisans, should be revised by the townsmen; and what exceeds the compass of their understandings, must be heard by appointed judges. The members of a court of judicature are superior in jurisdiction to the kindred and the rest; the chief judge is superior to them; and the king is above all, since causes are always justly decided by him : for the intellect of the sovereign surpasses the understandings of others, in the trial of the highest, lowest, and mean controversies. $\$$

"The spiritual parent, the master, the family, the father, the eldest brother, and the grandsire, should try controversies among men, in matters to which they are competent.\|

"Litigants who have been before a previous tribunal, resorting, whether justly or unjustly, to the king, become plaintiffs [in appeal.]

"One, who had been heard before the village, may appeal to the town ; he, who has

\footnotetext{
* Dév. Eh. in Sm.Ch. $\quad+$ Yájnyawalcya, 1.30. $\quad \ddagger$ Náreda, 1.8.

$\oint$ Vrihaspati, cited in Viramitr., and partially in Iyav. Chint. and Dípacalicá.

II Iyása, cited in Mádh. T Pitámaha, cited in Sm.Ch.
} 
been before the town, may resort to the king; but one, who has been tried by the king, whether ill or well, has no further appeal.*

"A cause, which has been tried by the kinsmen, must be revised by successive judicatures, if either party be dissatisfied, until it be finally decided by the king. But they who pass decisions in law-suits without being properly authorized, are guilty of assumption of royal functions, and the king shall inflict punishment on them accordingly. Yet persons wearing the token [of a religious profession], companies [of artisans], assemblies [of co-habitants], merchants, and bodies of armed men, should always adjust their affairs according to their own laws. $\dagger$

"Among merchants, artisans, and the rest, as well as among such as subsist by agriculture, painting, and dyeing, since a decision cannot be passed by others, the king should cause their disputes to be adjusted by persons acquainted with the principles [of their calling.]

"Husbandmen, mechanics, artists, men of a low tribe, dancers, persons wearing the token [of a religious order], and robbers or irregular soldiers, should adjust their controversies according to their own particular laws. $\$$

"The king should cause the disputes of men who practise austerity to be settled by persons conversant with three sciences, and not decide them himself, lest he rouse the resentment of adepts in illusion. $\|$

" Persons are appointed to try causes, according to the situation of the people concerned : the king and the society should adjust the matter conformably with justice. So Bhrügu ordains. He should cause the instruction [which shall determine the controversy] among men of the highest tribe, spiritual parents, venerable preceptors, and austere devotees, to be delivered by a person endowed with thorough knowledge. $\uparrow$

"Let not a prince, who seeks his own good, pronounce the law among twict-born men, who dispute concerning affairs relative to the several orders: but let him, after giving them due honour, according to their merits, and first soothing them by mildness, apprise them of their duty with the assistance of bráhman'as.***

"Judges appointed by the king are persons authorized by him to try causes. Assemblies (puga) are meetings; companies are associations of persons subsisting by the same mechanical employments; families are societies of husbandmen. Among these, the first being superior to the last in order as enumerated, their relative authority in the trial of causes follows the same order. Therefore, when a cause has been tried by the family (cula), if there be suspicion that it has been ill decided, a revision by the company of fellow artisans is proper. When it has been tried before the company ( $s^{\prime} r^{\prime} e^{\prime} i$ ) the revision is by the assembly; or, tried before the assembly (puga), it is reviewed by the king's judges, and not conversely.t+

\footnotetext{
* Pitámaha, cited in Sm. Ch. and Mádh. $\quad$ Cátyáyana, cited in the Calpataru.

I Vyása, as cited in Mádh. and V'iramitr.; and Náreda quoted in Tyav. Chint. and Cáyáyana, in C'alp.

$\$$ rrihaspati, cited in Calp. and Tiramitr. \| rrihaspati and Cútyáyana, cited in Calp. ryar. Chint.. \&i.

T Cátyáyana, cited in Calp. *** Menu, 8.390-391. H† Aparárca on I'ájnyaúalcya, J. 30.

Vol. II.

$2 \mathrm{~A}$
} 
“An assembly (puga) signifies a meeting; for $\mathrm{CA}^{\prime} \mathrm{TYA}^{\prime} \mathrm{YANA}$ 's text expresses, that a meeting of traders and the rest is termed puga. An assemblage of persons of different classes is a company (s'ren'i): one of persons of the same class is a family (cula). When these are appointed by the king for the decision of causes, the first respectively must be deemed superior to the latter; and this superiority is relative to appeal and revision. Thus, when a cause has been tried by an assembly, it must not be reheard by a company. By these several authorities causes may be tried, except such as concern violent crimes. So Vrĭhaspati declares.**

" Judges appointed by the king are members of a court of judicature nominated by the sovereign to administer justice. Assemblies are multitudes or meetings of persons belonging to different tribes and following different avocations, but inhabiting the same place, such as villagers, townsmen, or citizens. Companies are conventions of persons belonging to various tribes, but subsisting by the practice of the same profession, stich as watchmen, dealers in betel, weavers, curriers, and the rest. Kindred signify meetings of relations connected by consanguinity. Of these four, namely, the king's judges and the rest, that jurisdiction which is here first mentioned must be deemed relatively ' superior,' or possessed of higher power 'for' the decision of law-suits,' or trial of causes 'among men ;' that is, between litigant parties. The meaning is, that in a cause decided by judges appointed by the king, the party that is cast cannot revive the suit before the townsmen and the rest, although he be dissatisfied, thinking the decision unjust. So, in a cause decided by the co-habitants, there is no resont to the fellow-artisans; nor, in one adjudged by them, to the kindred. But, if it were determined by the family, it may be appealed to the craft, and so forth. In like manner, if it be decided by the company of fellow-artisans, it may be appealed to the assembly; or if arljudged by the assembly, the next resort is to judges appointed by the king; and $\mathrm{N}^{\prime} \mathrm{REDA}$ declares, that in a stiit tried by the king's judges, a further appeal lies to the king in person. Moreover, when he is resorted to, and the appealed cause, whereon a double amercement is staked, shall be decided by the king, aided by other assessors, together with the former judges, should the appellant be cast, he shall be amerced; or if he gain the cause, the former judge shall be fined.

"A cause tried by inferior judicatories may be appealed ; but the judgment passed in

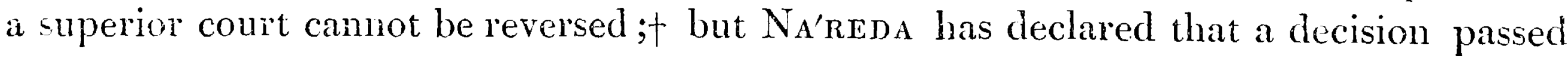
by judges appointed by the sovereign, may be reversed before the king in person. Here the mention of hing sub-denotes the chief judge; for he is superior in comparison with persons appointed by the sovereign. Therefore, a decision passed by persons so appointed, may be revised before the chief judge; and one by him adjudged may be rescinded before the king. Here, on appeal to the king, when a cause upon which an amercement is staked against the first judges is tried by the king, assisted by other assessors, should the appellant be cast, he shall be fined in a double penalty;

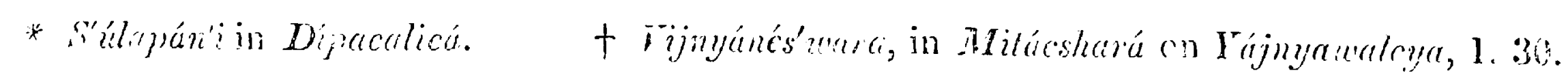


but if he gain the cause on appeal, the original judges shall be fined, as the law provides. That will be explained in another place.

"Is not the trial of causes by townsmen and the rest impossible? How then can one jurisdiction be superior to another? For it may be asked, have they power to try causes in their own right, or by delegation from the king? The one supposition is not correct ; for the appointment of a chief judge as assessor and representative of the monarch, and that of the spiritual advisers, the ministers of state, and judges as assessors only, is exclusively propounded. Nor is the other supposition right; for those only who are empowered to protect the people are invested with authority of inspecting judicial affairs : others, then, cannot possess that authority in their own right.

"It is thought that townsmen and the rest have power to try law-suits between merchants and others by the king's special appointment only, because it appears from texts of $\mathrm{VYA}_{\mathrm{Y}} \mathrm{Sa}$, Vrĭhaspati, and others, that they are appointed assessors in the mode before explained.

"That is wrong. For if such were the case, the power of trying all causes would belong to the king and the chief judge exclusively, because no others could try suit: without reference to them; and, since it is a maxim that denominations are taken from the principal object, the rule, that suits determined by kinsmen, \&c. may be appealed, would be impertinent, for none could be determined by them. Townsmen and the rest could not themselves try a suit with delegated power, because it is forbidden to delegate. judicial authority to S'ídras; now the townsmen and the rest mostly belong to the servile class, and even to the lowest tribes of it, sprung in the inverse order of the classes.

"To all this the answer is, admitting that townsmen and the rest could not themselves try suits, still, in law-suits between merchants and the like, the charge is brought by persons of that description, and the king and the judge rely on such persons in deciding the cause. Taking their acts as the chief objects, the denomination may be fitly assumed from what is done by them. For the purpose of regulating the appeal, when a law-suit is recommenced, under a notion that it was ill decided, their consecutive authority is propounded by the text: else the precept would be irrelevant:

" But, in fact, townsmen and others, though persons to whom delegation of judicial authority is forbidden, are regenerated as to the cognizance of suits between fellowtownsmen and the rest; for a person to whom judicial power may be delegated, is not restricted by the texts of $\mathrm{V}_{\mathrm{YA}} \mathrm{SA}_{\mathrm{A}}$ and others to the cognizance of certain particular charges. Their power of themselves trying causes, like the chief judge, may therefore be affirmed. Consequently there is nothing impertinent. Moreover, Vhühaspiti supports this very doctrine.*

"Kindred are relations of the parties. By the term ' and the rest' [in the text., " $^{\circ}$ Vrĭhaspati], companies and classes are meant. A company (s'rén'i) is a convention of merchants, and so forth. A class (gan'a), is an assemblage of priest. S.. Membirs on 
a court of justice are authorized judges. The chief judge is the superintendent of the judicature. Among these, including the king, the last in order has superior jurisdiction in the trial of causes, on account of pre-eminent knowledge.*

"The reason of the law is this: kindred and the rest, being related by consanguinity or other tie, may decide unjustly, through partiality or a like motive. Ari appeal, therefore, lies to the king and other authorities, on alleging, with probable truth, that the cause had been ill decided. Fellow-artisans have superior jurisdiction above the kindred, because they are alien to the parties. But townsmen, though the single connexion of a common residence exist, have superior authority, because they are strangers to the parties, with no mutual relation, since they belong to different tribes and follow other professions. Persons appointed by the king, being still less connected with the parties, have jurisdiction above the co-habitants, because men appointed by the king, after due examination, cannot be susceptible of the influence of partiality or the like motives, since they are under awe of the sovereign. Assuredly, for the two reasons above-mentioned, the chief judge, the domestic priest, and the ministers of state, have superior authority. The impartiality of the king is obviously and absolutely certain, for he is intrusted with the protection of the people; partiality would in him be a still more heinous sin; and he must apprehend the temporal and evident evils arising therefrom, such as perturbation of the people, and so forth : since it is a maxim, ' when the prince commits injustice, who can restrain him?' His jurisdiction is therefore superior to all. The comparison of intellect, too, is expressly noticed in the text of VRüHASPATI.十

"Husbandmen, in the subsequent text of VRĭhaspatr, are cultivators of land. Artisans are painters, \&c.

"Husbandmen, or cultivators; mechanics, carpenters, and the rest; artists, painters, \&c.; usurers, lenders at interest; persons wearing the token, \&c.; pás'upata, and other heretical sects: these and the following texts are not intended to prohibit the king's hearing such law-suits, but to show that in cases of this kind, since the suits are brought against merchants and the like, such persons should not be excluded from the trial and decision of the causes. $\$$

"The trial of law-suits between persons whose resentment is formidable, should be conducted through the intervention of people belonging to the same class. The several orders are those of students in theology, and so forth. If there be a variance of opinion on the question, what is, or what is not ordained, the king, even though he enter on the inquiry, should not expressly declare the law, lest he excite the anger of the party that is foiled. First assuaging the wrath of these persons by mildness and gentle discourse, let him then inculcate their duty on them through the intervention of brálman'as.\|

"Among twice-born men, amidst whom a controversy has arisen concerning affairs relative to the order of a householder, "whether this be the sense of the law, or that

\footnotetext{
- Váchaspati mis'ra in Iyavahára Chintáman'i. $\quad+$ Mitr. mis'r. in Viramitr.

$\ddagger$ Lacshmidhara, in Calp. $\quad \oint$ Mitr. mis'r. in Viramitr. $\|$ Vúch. mis'r. in Vyav. C'lint.
} 
be its true interpretation,' the king, desirous of effecting his own good, should not with violence pronounce positively what the construction of the law is. Having shewn them that honour which is their due respectively, he should with aid of other brámman'as, after previously extenuating the presumption by his kindness, apprise them of that which is their duty.*

"Concerning affairs relative to the several orders, as that of student in theology, and so forth, let not the prince pronounce the law; let him not specifically declare it; let him not adjudge victory and defeat. By mildness or conciliatory discourse, soothing them, or appeasing their wrath and other passions, [let him apprise them of their duty."]†

\section{§ 3. Members of a Court of Judicature.}

"The king and his officers, the judges, the sacred code of law, the accountant and the scribe, gold, fire, and water, are the eight members of the judicature. $f$

"A court consists of eight members, the scribe, the accountant, the sacred code, the sequestrator of the goods claimed, the judges, gold, fire, and water. $\S$

"The king, the appointed [superintendent of his courts], the judges, the law, the accountant, and the scribe, gold, fire, and water, and the king's own officer, are ten members of legal redress. A court of judicature is a body composed of these ten members; and such a court, wherein the king presides and attentively inspects the trial of causes, is a meeting sanctified by solemn acts of religion.

"The office of those several members is separately propounded: the chief judge is the organ of the court; the king is the dispenser of justice; the assessors investigate the merits of the cause; the law dictates the decision of the case, namely, judgment [in favour of the one party], and a fine imposed on the other; gold and fire serve for administering oaths; water for relieving thirst or appeasing hunger; the accountant should compute the sums; the scribe should record the pleadings; the king's officer should compel the attendance of the defendant and of the witnesses, and he should detain both the plaintiff and the defendant if they have given no sureties.

"Among these members of the judicature the king is the crown of the head; the chief judge is the mouth; the assessors are the arms; the law is both hands; the accountant and the scribe are the legs; gold, fire, and water, are the eyes; and the king's officer is the feet.ll

"The court of judicature is a body in shape of an assembly, and composed of ten members; in which assemblage, likened to a body, the king presides as its soul. It is thus intimated, that as the soul animates the corporeal frame, so the king, presiding:

\footnotetext{
* Cullica Bh. on Menu, 8.390.391. † Lacshm. in Calp.

† Náreda, 1. 16. $\quad$ Prajápati, cited in the $S m$. Ch.

I| rrihaspati, cited in Calpataru and liramitródaya. Some stanzas are transposed in the first-mentionil compilation.
} 
over the court and its members, and inspecting all its acts, both enjoys and confers the consequent benefits.*

"In NA'REDA's enumeration, the king and his officers are considered as one member of the court; consequently there is no reason for supposing the number of nine." $†$

\section{\$ t. The Sovereign Prince.}

"The king, or a very learned bra'hman'a [entitled judge], shall decide the various sorts of law-suit. $\neq$

"Let a man of the royal tribe, who has received the investiture of sovereignty, or one of the sacerdotal class who is conversant with many sciences, ascend the tribunal without ostentation [in his dress or demeanour], and inspect judicial proceedings. $\S$

* The king, associating justice with himself, and devoid of partiality or malice, thould thoroughly investigate the affairs of contending parties.\|

" Divested of wrath and avarice, let the king inspect law-suits with the aid of learned priests, according to the sacred code of justice. I

"The king should repair to the court of justice, sedate in his demeanour, and without ostentation in his dress; and sitting there, or standing, with his face turned towards the east, should examine the affairs of litigant parties; he should be attended by assessors, firm in the discharge of their duties, intelligent, sprung from a noble root, belonging to the highest class of regenerate men, skilled in expounding the sacred code, and perfectly acquainted with moral discipline. Thus calm and unostentatious, attended by the stpeintendent of his courts of justice, by his ministers of state, by brálman'as, and by his own domestic priest, he should himself adjudge the gain and loss of the litigants' causes. A prince who judges the suits before him, abides accordingly hereafter in a region of bliss, together with the chief judge, the ministers of state, the attending britmancis, his own domestic priests, and the assessors of the court.***

"The king himself should inspect forensic affairs, with the aid of learned priests, ot appoint a brikman'a to try causes.

"Let princes of the military class administer justice in their own dominions respectively; but an eminent brihmania should act for any other sovereign.” $ł \ddagger$

\section{\$. 5. The Chief Judge.}

"Placing the sacred code of law before him, and abiding by the advice of his chief judge, let the king try causes with composure in regular order. $\$ \oint$

"Let the king or a twice-born man, as chief judge, try causes; setting the members of the juclicature before him, and abiding by the doctrine of the law, and by the opinion of the assessors. || $\|$ 
"When the king cannot inspect forensic affairs in person, let lim appoint for the inspection of them, a bráhman'a of eminent learning.:

"By a prince, whom urgent business (or disease, or other cogent reason) prevent: from trying causes in person, a bráhman'a, thoroughly acquainted with all [civil and religious] duties, must be appointed, together with assessors, [to examine all causes]. $\dagger$

"When the king is prevented [by the exigency of affairs] from superintending the decision of causes, let him appoint a learned brúkman'a, perfectly conversant with sacred literature, patient, sprung from a good family, impartial, deliberate, firm, arred by the dread of another world, virtuous, diligent and placid. $\neq$

" Of him who neglects employing regenerate men, and inspects forensic aifairs with persons of the servile tribe, the kingdom totters, and his wealth and power pass awar.

" [The king should administer justice,] or appoint a brillman'a to try the causes.

"A Ariaman'a, supported only by [the profession of] his class, or one barely reputed a britman'a, may at the king's pleasure interpret the law to him; but not a s'atia by any means. Of that king, who stupidly looks on while a s'udra decides causes, the kingdom itself shall be embarrassed, like a cow in deep mire.शा

" He [the judge] interrogates, and is therefore the interrogator (iprit'); and he discriminates, and is consequently the discriminator (virúca). **:

"Because, having inquired the transactions relative to the matter in dispute, he carefully investigates the merits of the suit, with the assessors; therefore is he called the chief judge. + 十

"He inquires the question whereon the law-suit is founded, and is thence named the interrogator; and because he examines into it, he is termed the chief iudge. $\neq \neq$

"In a controversy, he inquires the question which is agitated, and the answer which is given: having interrogated the parties with gentleness, he pronounces judgment, and therefore he is called the chicf judge. $\delta 5$

"The most momentous of all obligations is the declaration of the truth to the juuge [who interrogates]. \|\|

"Being conversant with the eighteen topics of litigation, and with the thousand and eight subdivisions thereof, and being skilled in logic and other sciences, and perfect?. acquainted with scripture and jurisprudence, he inquires the law relative to the contriversy, and investigates the matter in question, and is therefore called the chief juige. Ev

"A person, not austere, bit gentle and tender, the hereditary servant of the state, wise, cheerful, and disinterested, should be appointed by the king for the trial of causes.**:*

"When the king tries causes in person, this officer is his colleaghit in the admin:istration of justice; but when he is unable to inspect judicial affairs himseli, by reasm

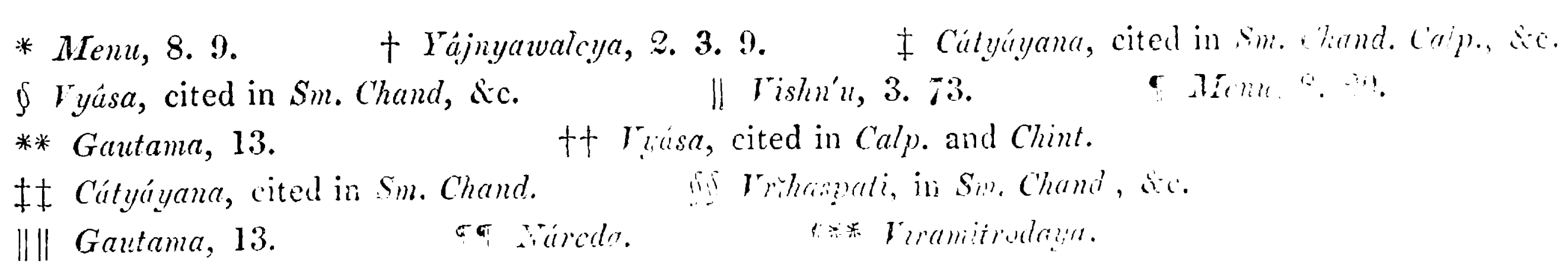


of other urgent business, or through want of health and ease, the chief judge is his representative.*

"The denomination of chief judge is a derivative term. He interrogates the plaintiff and the defendant, and is thence named the interrogator. With the assessors he discriminates or investigates the consistency and contradiction of the allegations on both sides, and is therefore called the investigator. He is both interrogator (prát') and investigator (viváca), and he is for that reason entitled chief judge (prád'viváca).†

"The judge interrogates the plaintiff and the defendant, and is therefore termed interrogator. Investigating with the assessors what is affirmed by the parties, he pronounces judgment, and is thence denominated the pronouncer (vivica). VYA'SA, using the word investigate, indicates this derivation of the term; he who discriminates is the discriminator (viváca). But Gautama defines it thus: he pronounces after investigation, and is therefore entitled the (vivica) pronouncer of judgment.

" He asks the plaintiff, what is your complaint? and the defendant, what is your answer? and he is consequently the interrogator. Having heard them, he distinguishes or pronounces the gain or loss of the cause, according to right and wrong, and is therefore pronouncer. $\$$

"He inquires the charge, and is consequently the interrogator; he awards ordeal suitable thereto, and is therefore awarder. He both interrogates and awards, and is thence so entitled. He should inquire the transaction, and then examine into what is alleged by the two parties. $\|$

"He questions both parties, the plaintiff and the defendant, and is therefore the interrogator: and he specially pronounces judgment, and is consequently the adjudicator. Thus the appellation is etymologically significant. It is exhibited by $\mathrm{N}_{\mathbf{A}^{\prime} \mathrm{REDA}}$ in a different manner explanatory of the learning which he should possess. Thus by stating the derivative sense of the term, both legislators do virtually propound the duties of the chief judge." $\pi$

\section{§6. The Assessors.}

"Let the king, accompanied by three assessors at the least, enter the court-room; and there, either sitting or standing, try causes.***

"Let the chief judge, accompanied by three assessors, enter the court-room; and either sitting or standing, try the causes brought before the king. In whatever place, three bráhman'as, skilled in the védas, sit together with the learned brálman'a appointed by the king; the wise call that assembly a court of judicature. H

"Wherever seven, or five, or even three, bríhman'as, versed in sacred and profane literature, and acquainted with the law, sit together, that assembly is similar to a meeting for a solemn sacrifice. 拉

\footnotetext{
* Viramitródaya.

† Mitácshará on Yájnyawalcya, 2. 3.

† riramitródaya.

$\oint$ Raghunandana in Vyavahára-tatwa.

II Same in Divya-tatwa.

- Smriti Chandricá.

* Vriluaspati, cited in Sm. Chand. †十 Menu, 8. 10.11. 拉 Vrǐhaspati, in Mit. Calp. and Mádh。
} 
"In $\epsilon$ very law-suit, several per'sons, conversant with many sciences, must be appointed to try the cause: a prudent man should not trust a single individual, however virtions he may be.*

"Let persons, who are conversant with sciences and holy studies, acquainted with the law, habitually veracious, and strictly impartial towards friend and foe, be appointed by the king assessors of the court.

"Twice-born men, disinterested, opulent, acquainted with jurisprudence, habitually. reracious, and skilled in all sacred sciences, should be appointed bir princes asseson. of their courts of judicature. A man, who has studied but one science, would not know how to pass a just decision in a cause; therefore should one who has many attainments, be appointed by the monarch supreme in the trial of forensic controversies. If there be no learned priests let the ling appoint a man of the military class, o: one of the commercial tribe, who is conversant with jurisprudence: but let him carefully avoid nominating a s'adra. Whatever act shall be done by others, than such as lice described, though they be formally apointed, must be conidered as an illegal pricceeding, even though it chance to be confomable with the law

"Men, qualified by honesty and religous ac's, strict in veracity, and attentive to their duties, void of wrath and avarice, and conversant with the institutes of law, shoult? be appointed by the ling assessors of the court.j

"Persons, qualified by birth, religious acts, and rigid observances, and who are impartial towards friend or foe, and incomptible by the parties in the cause, throurt any means whatsoever, whether by infuencing their lust, writh, fear, avarice, or other passion, should be appointed by the king asescons of the court.

"The king should appoint, as members of the court, honest men of tried interity, who are able to support the burcien of the administration of justice like bulls (bearing a heary load). The assessors of the king's conrts of judicature should be men sliiled in jurisprudence, sprung from good families, rigidly veracious, and strictly imparia! towards friend and foe.

"They, who are unacquainted with the customs of the country, who hold atheistical tenets, who neglect the sacred code, and who are insane, passionate, araricions, or diseased, must not be consulted in the decision of a canse.***

"Let the bratman'a, who has been appointed by the king to be chief judge, beins: accompanied by three bramanas, who are learned men, fit to sit in the court, and conversant with the trial of causes, enter that court, and there sitting or standing, but not moving to and fro, lest his attention should be distracted, try the causes relative to matters of debt or other litigated topics, which are depending for trial before the king, In whatever spot even three bráman'as, learned in the three réals (rich, yajush and siman) sit; and with them the learned bramaina who has been appointed by the ling:

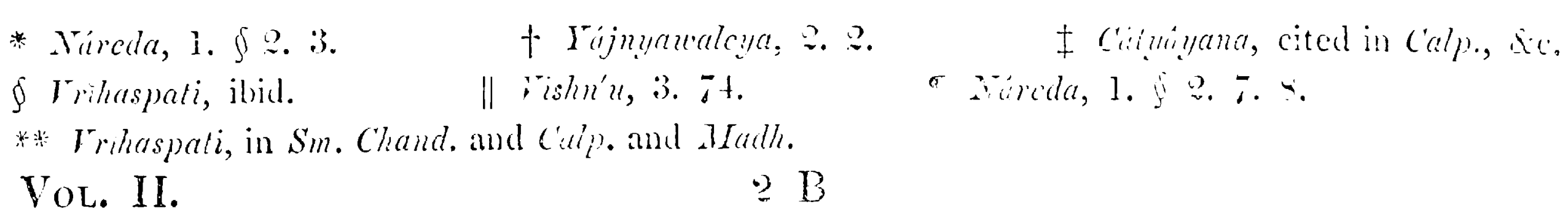


also sits; people deem such an assembly similar to the court of the god with four faces (Brahmá).**

"Accompanied by three assessors at the least; not by so few as two or one. $\dagger$

"The assessors appointed should be three: for such is the import of the plural term. But they may be more, either five, or else seven. $\neq$

"The implied sense is, that fewer than three should not be appointed, nor more than seven. The uneven number is intended to show that, in case of disagreement, the opinion of the greater number should be respected, since it is a rule, when the meny and the few disagrce, that the judgment of the majority shall prevail: provided, hoverer, their qualifications be equal. But, if these be unequal, the opinion of the hest quaified ought to prevail; agreeably to the saying, 'even a hundred blind men cannot see.'

"Persons, possessing the qualifications described; namely, conversant with philosophy, grammar, and other sciences, familiar with the study of the védas, acquainted with the law, being versed in the sacred code of justice, endued with the quality of speaking the truth, and impartial towards friends and foes, being divested of malice, affection, or passion; should be appointed by the king assessors of the court (sablásad). They should be induced by presents, reverence, and courtesy, to sit (sad) in the court (sabhá) or assembly.\|

" They should be persons sprung of noble families; descended both on the father's and on the mother's side from ancestors free from any stain, such as that of a mixt class or other clebased origin. .

"By others (than such as described in the text), though formally appointed, yet destitute of the requisite qualifications, if a decision consonant to law chance to be onssed, still it must be considered to be inconclusive."**

"By valuable presents, by courtesy, and other conciliatory means, the king should induce qualified persons not to decline sitting in court for the trial of law-suitsott

"The assessors should be persons incorruptible by the parties in the cause, through ny mens whatsoever. They should be such as cannot be gained $b_{y}$ the litigint purties.市方

" Wot to be influenced by the parties or litigants acting on their passions."

\section{The Audience.}

"Whether appointed or not appointed [to be a member of the court], one, who is skilled in jurisprudence, has a right to speak: for he, who lives in strict observance of the law, delivers a speech, which the gods approve: $\$$ or [as the reasen is given by mother author] for that which he deliberately pronounces in the court, is doubtless conformable with the law.\|l

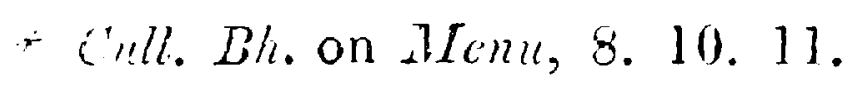

† Div. Bh. in Sin. $\mathrm{Ch}$.

Mitr. mis'r. in riraniti.

II ritit. on Yájn.

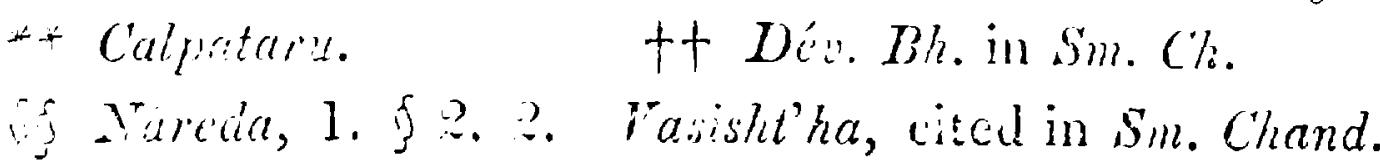

† Mii. on Yian.

if Ragh. in ryau. talwa.

市 Lacshm. in Calln.

ill Vrihaspati, cited in Calpatarit.
} 
"One who is not appointed (nor is qualified to act as judge) must on no account speak at the trial of a law-suit: but by him, who has been appointed, an impartial opinion ought to be given.**

"Either the court must not be entered, or law and truth must be openly declared; but that man is criminal who either says nothing, or says what is false and unjust. $\dagger$

" Either the court should not be entered; either the duty of inspecting law-suits should not be accepted; or, if it be accepted, the truth should be spoken. When the judges are deciding unjustly, the wise do not approve the silence of one even who has approached the court of his own accord, not being regularly appointed.f

"One, who is conversant with the law, has a right to declare his opinion, though he be not formally appointed to assist at the trial. $\$$

"If the king, notwithstanding proper and legal advice, given by the consitituted judges, should act unjustly, he must be checked by them, else they incur blame. Again, if persons, who are not formally appointed, tender wrong advice, or none, blame falls on them; but not for omitting to check the king when he persists in acting illegally.\|

"The court should be surrounded by a few men of the commercial tribe, assembled in a group, persons mild and well disposed, advanced in years, of good families, opulent, and devoid of malice. .ा

"Merchants should be hearers of what passes at the trial of causes.**

"To restrain the populace, the court should be encompassed by a few men of the mercantile tribe, + forming a throng." $ł \ddagger$

\section{\$ 8. The Domestic Priest or Spiritual Adviser.}

"The king should appoint for his domestic priest, a diligent and faithful brituman' conversant with sciences and sacred duties, disinterested, and rigidly veracious. $\$ \$$

"For releasing a criminal who ought to have been punished, the king must fast one night; and his domestic priest three. But, for inflicting pains on one, who shon? not have been chastised, the domestic priest must observe the severe fast; and the king, that which lasts three nights. ||

"A domestic priest must be appointed by the king for the inspection of judicial proceedings, in like manner as he is delegated for the celebrating of lustrations and other religious ceremonies. If

" Only one domestic priest is appointed. The singular number therefore is here purposely employed: for the object is attained by a single appointinent.

"The king should be checked by the domestic priest, if he act unjustly, partially. or perversely. Accordingly VASisht'Ha ordains penance for the domestic priest, as vell as for the king, when the penal law has been contravened." ****

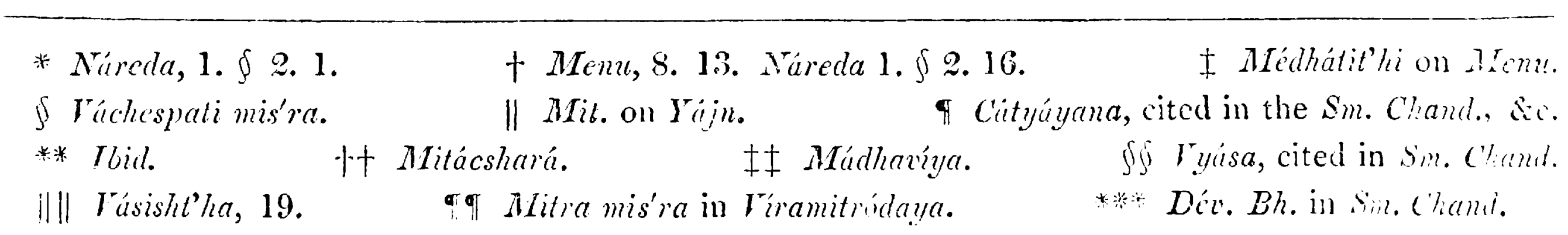

$2 \mathrm{~B} 2$ 


\section{Ministers of State.}

"When tired of overlooking the affairs of men, let the king assign the station of inspector to a principal minister, who well knows his duty, who is eminently learned, whose passions are subdued, and whose birth is exalted."

"Let the king appoint for his counsellor a priest or a twice-born man, perfectly conversant with the sense of all the sacred institutes, levoid of avarice, a just speaker, intelligent, and who has been uniformly employed in the royal service.

"The king must appoint seven or eight ministers, who must be sworn; men who are hereditary servants of the throne, who are versed in holy book, who are personally brave, who are skillsal in the use of weapons, whose lineage is noble.t.

"Althongh the text specify a priest, the word twice-born is nevertheless added, to show that, for want of such a learned priest, the ling may appoint for his minister a cshatriygl, or a rais'ya, but not a s'údra.

"Minister is here expressed in the singular number with an indeninite sense; for it is only meant to enjoin the appointment (not to prescribe the number), and hines directs the king to repair to the count with maxy comnellous."

\section{\$10. Oficers of the Court.}

"They who are suborilinate to the court are properly called the king"s officers; the

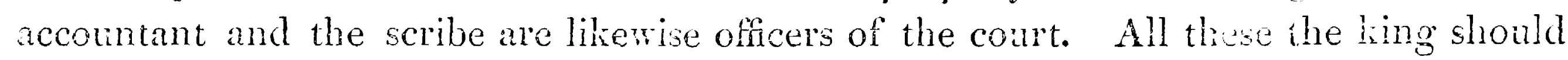
require to attend the judicial assembly. $\|$

"Two persons, versed in samma and language, skilled in computation, pure in conduct, and well acquainted with various modes of writing, shoul! be appointed by the king to be respectively accountant and scribe. T

"The ling should appoint as accountant one who is versed in the dhree branches of mathematics, who is clearly deserving of trust, and who is conversant with sciences and sacred studies.**

"Let him appoint, as scribe, one whose diction is unambiguous, whose hand-writing is fair, and who is lonest, placid, disinterested, and strictly veracions.****

"A Anan of the surile trite, who has been mifomly employed in the ling's service, and will be fim and strictly obedient to the judges, should be appointed by the ling to be keeper of things clamed and enforcer of the recovery.***

i I man of strict veracity must be nominated by the king as his ovn officer, under the control of the judge, to summon the parties, to hold them in custody, and to seek their witnesses.

" He who recreates tie plaintifir and defendant, the judges, the scribu, and the accountant, with discourses on morality, holds the office of moderator of the couritt

"The accountant should be a person versed in the science of astronony, compre-

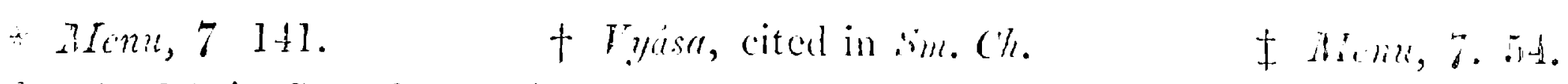

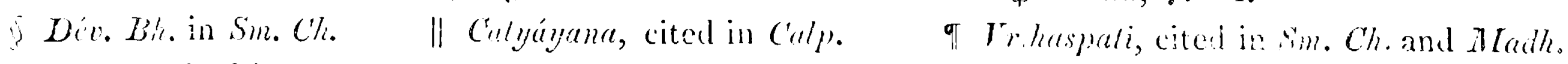
Fyisi, cited in the same.
卟 rihaspali, cited in the sam.
It rikasa, ib. 
hending three branches, entitled horí, or astrology; ganita, computation (arithmetic, algeba, and mensuration), and sanhitá, or body of astronomy. 'The condition, that he be conversant with sciences and sacred studies, implies that he must belong to a regenerace tribe; and the scribe, mentioned in the same place, should likewise be a twice-born min. To show that the leeper of things claimed need not be so, the same author say of him, 'a man of the servile tribe,' \&c.*

"6 'The ling's own officer,' is a messenger placed under the control of the judges to summon parties, \&x.

"The moderator of the court, or diverter of all parties, may belong to any one of the four tribes, since no meference is intimated. But according to the Smriti Chandricu, he should appertain to one of the three first tribes, since the nomination of a s'udra to an offee in court is to be carefully aroided, as an ofience forbidden $\neq$

\section{$\$ 11$. Conduct of Judges, $\delta c$.}

Since $i t$ is one of the finctions of a sovereign to examine controversies in person, that daty is discharged by wise princes in the manner enjoined by law. Therefore should a king thoroughly muard his realm with care, by the due administration of justice, so will his wealth, virtue, and royal power be increased. Let him not side with either party, forgetting Yins's virtue of impartiality; but constantly inspect forensic affairs, banishing lustful and angry passions. $\$$

"To him who decides causes according to vestie, haring subdued his lustful and angry passions, subjucts fock as rivers flow to the sea. Like Muni, therefore, should the sovereign himself, forsaking favour and dishlke, practise the virtues of self-command, having conqueved his wrath and subdued all his passions.ll

"But a king, especinlly, who is careful to discharge his duty, must make strict ingairy to distinguish right from wong, becanse human intellect is confused. Liars compaed with verwous nen, sincere persons contrasted with insincere, appear in various shapes, and therefore trial and examination are enjoined. The sky seems to have a basis, and the luminary which shines in the heavens appears as fire; yet theie is no base to the sky, nor fre in the celestial luminary. Hence it is right to examine a fact strictly, even though it occurred in the inquirer's own sight: he, who ascertain facts by rigid investigation, deviates not from justice. A ling, thus constantly inspecting forensic afrairs with attention, here passes through a region of glory, and hereafter reaches the splondid alode of the sun. T

"A prince thus practising vighlance in the due alministration of justice, as ordained by hw, here passes through a region of glory, and hercifer becomes a counsellor of INDRA。****

"A king who acts win justice in defending all centures, and ways only the who

* Mér. Bh. in Sm. Ch.

f Ditr. mis'r. in Firamitr.

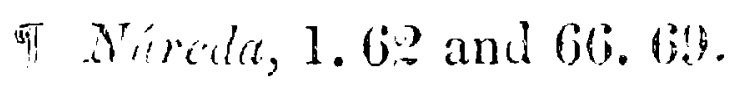

+ Hách. mis'r. in Vyav. Chinit, and Dív. Bh. in Sm. Ch.

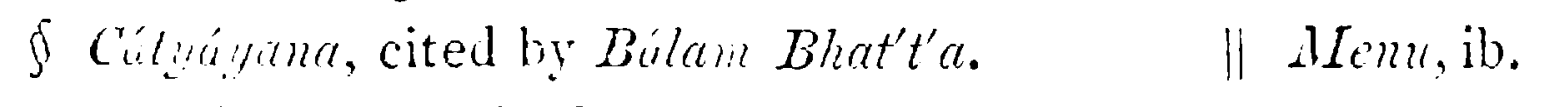

** Irihapati, cited by Bal. Bh. 
ought to be slain, performs, as it were, a daily sacrifice with a hundred thousand gifts. *

" A sovereign, who chastises those who should be chastened, and duly puts to death those who deserve capital punishment, performs a sacrifice with a hundred thousand gifts.

"A king, who inflicts punishment on such as deserve it not, and inflicts none on those who deserve it, brings great infamy on himself, and shall go to a region of torment. $\neq$

"Surely neither the king's brother, nor his son, nor his futher-in-law, nor his uncle, should be exempted from penalty for infringing their respective duties. $\$$

"A king is pronounced equally unjust in releasing one who merits punishment and punishing one who deserves it not; he is just who always inflicts the penalty ordained by law.

"As for the maxim that the king is the dispenser of distributive justice, it is intended to show, that he is exclusively invested with power to impose pecuniary penalties and inflict corporal pains; for reproof and imprecation may be used by the chief judge also; but the king alone is competent to exact a fine from one who is linble to amercement, and slay a man who deserves capital punishment. Reproof and imprecation are not restricted, because they are intended only for correction. Accordingly, after mention of the king or a very learned brílman'a, as the proper persons to decide suits, the legislator adds, "both reproof and imprecation are declared to be within the compe= tence of the priest; but pecuniary and corporal punishment appertain to the functions of the sovereign.' If It must be inferred that the judges and arbitrators, whether sitting in a stationary or in a moveable court, have only power to pass a decision; for by this text they are not competent to inflict any punishment whatsoever.***

"The chief duty of a prince invested with sovereignty by consecration and inauguration, is the protection of his people, and that camot be effected without restraining the wicker; nor can these be detected without inspecing judicial proccedings. Therefore should forensic añairs be daily inspected, as enjoined by the authortt in a receding passage. 'Reflecting apart on the reward of daily administering justice, cyual to that of a solemn sacrifice, the king should day by day inspect law-saits in person, arrounded by assessors.'tt

"Daily, except on the fourteenth day of every semi-lunation, and other excepted times. $\oint j$

"Let not the king do that which is inconsistent with revealed or memorial law, no: what is injurious to living beings: if that, which is so, be practised, let him check such conduct. Whatever has been inadvertently done, contrary to justice, by another monarch, let him redress according to maxims ordained by traditional law. $\|$.

\footnotetext{
* Menu, 8.396. † I'ímyawalcyi, 1.360. † Menu,8.128.

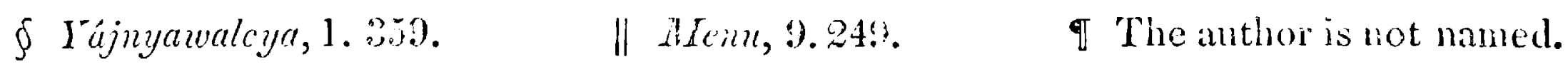

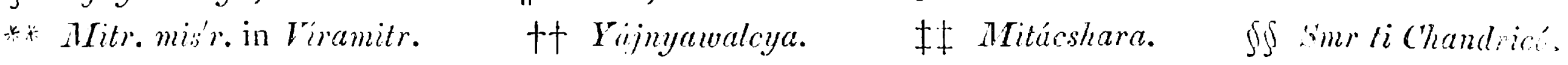

\|l| Núreda, 18.9.10. Tŭma, cited in Vyav. Chint. and Cályáyana, quoted in other compilations.
} 
"Traditional law is the Véda**

"Let the king carefully check, to the utmost of his power, whatever is contrary to justice; but if unable to do so, blame shall not be imputed to him: the wise restrict imputation of iniquity to wilful offences.

" Ere long his foes will subdue the wicked king, who decides causes unjustly through delusion of mind.t

"When the king issues an unjust command in the affairs of litigant parties, the judge should remonstrate with the king, and effectually restrain him. A just and impartial opinion must indispensably be delivered by a member of a judicial assembly; if the prince listen not to it, that judge is nevertheless exonerated. But, knowing the prince's mind to be diverted from the path of justice, still he must not fiatter him: a judge who so did would be criminal. Let not the members of the judicial assembly neglect to check the king when he acts unjustly; they who neglect it, fall headlong with him to a region of torture. Judges, who conform with him when he is disposed to proceed iniquitously, share his guilt. Therefore should the king be slowly advised by the members of the tribumal. of

"By saying slowly, $\|$ it is intimated that the judges should not, for fear of sin, abruptly at the instant oppose the king with their advice, but at another opportunity dissuade him. of

" A judge, who applauds an unjust sentence pronounced by the king, is criminal. Blame is likewise imputable to one who neglects to check the king when he deviates from the right path, and also to one who follows the king in his deviation from that patb.***

"Perceiving the prince's mind to be diverted from the road of justice, still he must not flatter him; and thus only the judge will not be criminal.t+

"He must not fiatter him by delivering an opinion simply in conformity with the king's inclination, but should opine strictly according to equity. Such being his conduct, the judge will not be criminal.łł

"When law-suits are justly decided, the judges obtain their own absolution, since their innocence depends on the justice of their decisions: therefore should equitable judgments only be pronounced.j\$

"The reward, as of a solemn sacrifice, belongs to him who, banishing avarice, hatred, and other passions, decides causes in the mode prescribed by law. The gods practise

* Iách. mis'r. in ryav. Chint.

+ Cátyáyana.

I Jinu.

$\S$ Cátyiyana, cited in Sm. Chand. Calp. and ryav. Chint. Several of the rorses are quoted as Nureda'sin Firamitr. and variations occur in the reading of the text.

$\|$ The reading here is slowly 'sánaih,' instead of 'sa taih,' by thom, as in other compilations, calp. Chint., Sic.

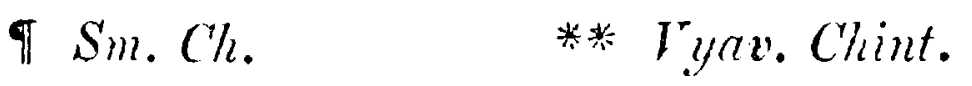

t十 C'atyayana, cited in Sm. Ch., but Náreda as quoted in Viramit.

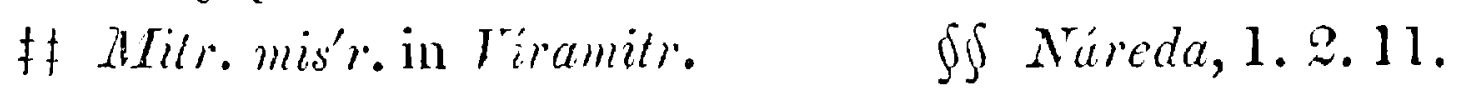


veracity, but men are conversant with falsehood; a divine character belongs, even in this world, to him whose sentiments strictly conform with truth.*

"As a blind man, heedless, swallows thorny fish; so loes he, who enters a court of justice, and there pronounces an opinion remote from equity and truth, through mistake of fints. $\dagger$

"A judge, pronouncing a fair opinion, incurs neither enmity nor sin; but one who acts otherwise, incurs bot?:.

"If the decision be at variance with iruth, the witnesses, the juiges, the superintendent of the court, and the sovereign of the land, forfeit confidence, loce stability, and fall to a region of toriure. $\$$

"When the judges, fully understanding the latent truth of the case, nevertheless pass judgment otherwise, and not as ordained by the law; when the cause is deciced in inch manner, then is tuth wounded by perjured wicked julges. Whenerer the sacres! code is transgressed by the judges in the decision of a cause, justice, being injured by iniquity, coubeless will cestroy thaze sinful men.

"The divine form of justice is representen as a bull showering boons; and the gods consider him who impedes justice as a slajer of a bull and hinderer of benefactions let no man, therefore, violate justice. The only firm friend who follows inen, creai aftor death, is virtue: every other is extinct with the bory. of

" Justice being destroyed, will dastroy; being preserved, will preserve; tieverue it must never be violated, lest, being ingued, it should cestroy [thyself and] us.**

"Justice, wounded by the shafs of falsehood, roars in the midst of the ascming against injustice set before him: this evil being should be slain, even by the vicked. th

"For where justice is dostroyed by iniquity, and truth by falsehood, whe julges who basely look on, shall also be dostroyed. if

"But judges who, repairing to he court, sit there in silent meditaion, and do not

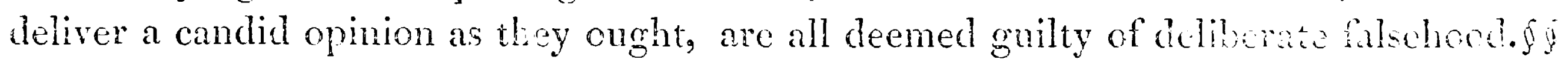

"When justice, wounded by iniquity, appronches, and the judges cutract not the dart, they also shall be wounded by it.lll

"As a surgeon draws a dart from a wounded body by cautions en.w. she whith the chief judge extract the dart of inichuity from the law-suit. Fा का

"When all the persons who are members of the julicial asembly opine "this in "ight, the suit is relieved from the dart of injustice; but otherwise it continues wounde? by the rankling dart. There is no judicial assembly wherein no elders st: noi are they elders who pronounce not an equitable judgment; nor is that an cquituble jumbmen! which truth does not pervade; nor is that trath which is contaminated with fraul."

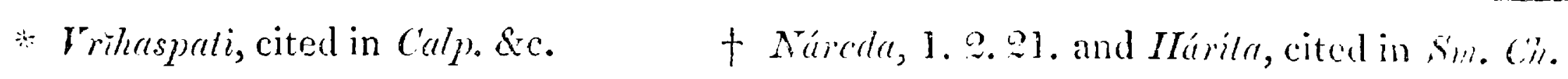

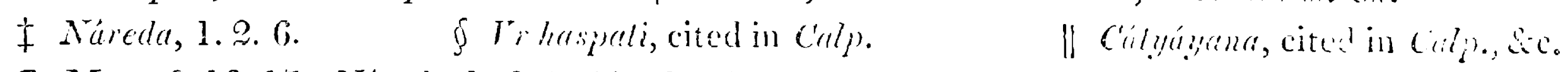

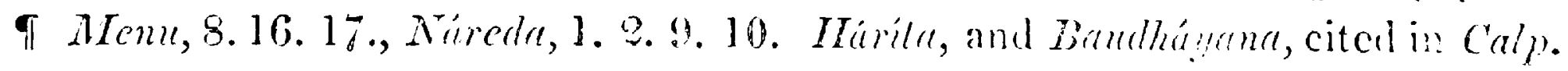

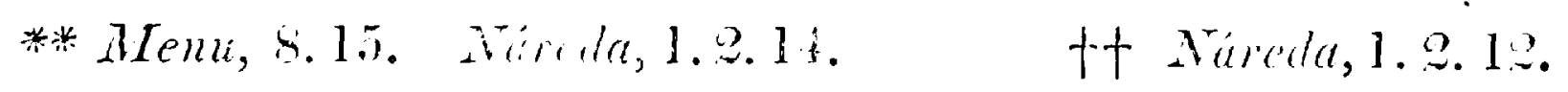

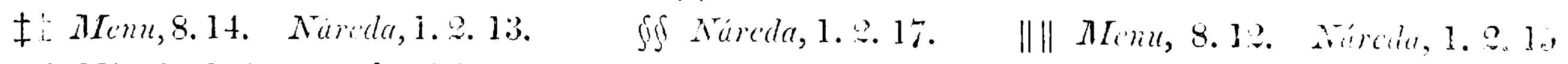

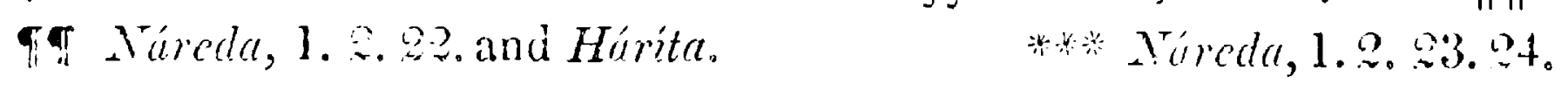




\section{§12. Punishment of iniquitous Judges.}

"Whether it be through passion, ignorance, or avarice, that a judge speaks otherwise [than truth requires], he must be considered as no assessor of the court, and the king should severely punish that sinful man.*

"Fully considering the just decision of the cause, let a judge pronounce sentence accordingly; a different opinion must not be given. He who does deliver an unjust sentence, incurs a penalty of twice the amount.

"Whether it be through affection, ignorance, or avarice, that a judge gives an opinion contrary to justice, he is declared by the law to be deserving of punishment. $\dagger$

" Judges who act contrary to law and usage, through fear, avarice, or partiality, shall be severally fined twice the amount of the suit.f

"Judges who give opinions inconsistent with law and equity; those who accept bribes; and men who defraud such as have trusted them; should all be invariably banished.ई

" Of false witnesses the whole property should be confiscated, and of corrupt judges.\|

"Those who accept bribes, let the king banish, having stript them of their wealth. I

"An iniquitous judge, a perjured witness, and the slayer of a priest, are considered equal criminals.***

"A chief judge, corruptly deciding a cause according to his own perverse will, though conscious that the opinion of the assessors is right, shall also incur punishment. +

"Whatever loss is sustained through the fault of a judge, must be fully made good by him; but the king should not reverse the judgment which has been so passed between the litigant parties, [or as differently read and interpreted, the king should investigate anew the cause which has been so decided].

"If the chief judge converse in secret with one of the parties in an undecided suit, he shall doubtless be liable to punishment; and so shall a member of the judicial assembly, who is guilty of the same collusion. $\oint \oint$

"A judge who gives an opinion contrary to justice, through the influence of affection or avarice, or through fear, should be fined in twice the amount of the penalty which is incident to the loss of the cause. $\$ \oint$

"The assessors before-mentioned, acting contrary to law, or inconsistently with the sacred code, or contrary to usage (as implied by the conjunctive particle), being overcome by ungovernable passion, through excess of affection, inordinate covetousness, or overpowering terror, shall be amerced respectively in twice the penalty which wonld be incurred by the party that is cast: not twice the value of the thing which was the subject of the law-suit: else it might be supposed that no fine would be incurred in the case of a trial for adultery or other matter [not pecuniary]. Partiality, ararice, and

\footnotetext{
* Núreda, 1. 60.

+ Cátyáyana, cited in Sm. Chand. Calp. and Madh.

I Iájnyazwalcya, 2. 4.

$\oint$ r rihaspati, cited in $S m$. Chand, \&c.

\| rishn'u, 5. 179. 1:1.

I Yájnyauralcya, 1.340.

* Irihaspati, cited in Iyav. Chint.

t+ Catyingana, cited in the Calp, \&c.

拉 ryav. Chint.

$\oint \oint D^{\prime} v$. Bh. in $S_{m}$. Chand.

VoL. II.

$2 \mathrm{C}$
} 
fear, are specified to restrict the precept which prescribes a penalty of twice the amount, to the instance of acting through partiality, \&c.; it shall not be incurred in the case of inadrertence, error, and so forth.*

"Judges passing a decision contrary to law, through the influence of passion, shall be severally fined in twice the amount of the thing which is the subject of the law-suit. This direction for imposing fines is applicable in controversies concerning valuables; but in other disputes, such as personal insult, \&c. a different punishment must be understood. Accordingly VISHN'U directs confiscation of property for acceptance of bribes; and here acceptance of bribes is stated merely as an instance. $\dagger$

" The offending judge shall be compelled to pay twice the penalty which is involved in the suit. This meaning, consonant to the interpretation of many commentators, nust be received. Not as it has been interpreted by a certain commentator, $\neq$ twice the amount of the thing which is the subject of controversy, for that is incongruous; and the incongruity has been shown by many authors: it is not here repeated, for fear of prolixity. $\$$

" $\mathrm{CA}_{A}{ }^{\prime} \mathrm{TYA}^{\prime} \mathrm{Y}_{\mathrm{ANA}}$ ordains punishment when the judge's fault is discovered subsequently to the decision of the cause. Though determined by a corrupt judge, the judgment is not io be rescinded by the king; but he should compel the iniquitous judge to make good the loss. $\$$

"The king should again try that cause which has been ill investigated and wrong decided.\|

"The same author provides that the chieî judge, or assessors, shall be fined even for merely conversing in private with either of the parties, previous to the decision of the cause. If

\section{§ 13. Court-House.}

"The place where the original matter is thoroughly investigated by a discuisition of law, is a court of justice.***

"The court of justice should be built on the castern quarter [of the king's palace]:†† and should be furnished with fire and water.

"In the middle of his fortress, let the king construct a house, apart [firom other" edifices], with trees and water adjacent $\oint \oint$ to it [or, according to a difierent reading, a large edifice encompassed with water\|\|l]; and let him allot for a court [an apartment] on the eastern side of it, with an eastem aspect, and duly proportioned, furnished too with a throne, decorated with wreathes, perfumed with fragrant resins, supplied with corn cmbellished vith gems, adorned with statues and pictures, and with imaces of doities, and accommodated likewise with fire and water. If |f

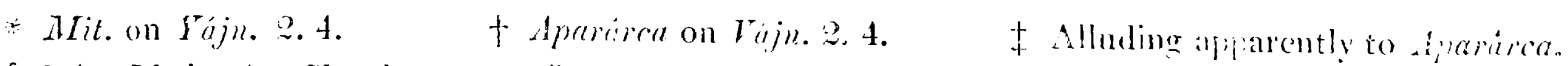

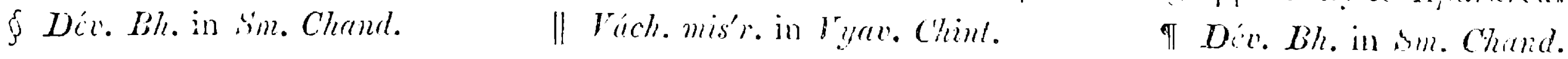

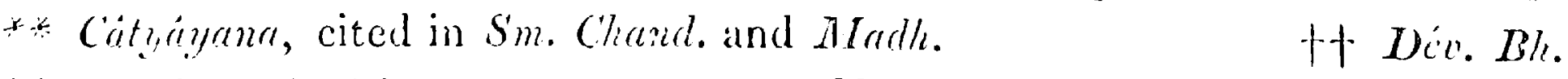

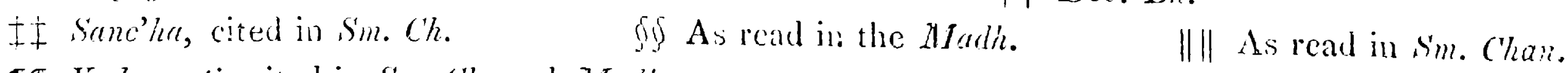

re rilhaspati, cited in Sim. Ch. and Madh.
} 
"An apartment for the assembly or court of justice should be allotted on the eastern side of the royal palace. It could be designed according to the dimensions taught by the rules of architecture. The place of assembly is termed a court of justice.*

" The place where a thorough investigation, or complete ascertainment of the original matter set forth, is competently instituted and conducted by means of a legal inquiry, and by persons qualified to decide, is called a court of justice (dharmidhicaran'a): a term signifying, agreeably to its etymology, a place where the original matter is thoroughly investigated according to rules of law." $\dagger$

\section{\$14. Time and mode of Sitting.}

"Having risen in the last watch of the night, his body being pure and his mind attentive, having made oblations to fire, and shown due respect to the priests, let him [the king $\ddagger$ ] enter his hall decently splendid. $\$$

"The king, having made oblations early in the morning and performed ablutions, and being composed and collected, and having shown due honour to his spiritual parents, to learned astronomers and physicians, to the deities and to brímmanas, and to domestic priests, with flowers, ornaments and vesture, and having saluted his spiritual parents and the rest, should enter the court-room with a cheerful aspect.\|l

"Let the king, uninfluenced by partiality, decide causes in the mode prescribed by law, during the forenoon, in his courts of justice; omitting the [first] eighth part of at day, but during [the next] three: such is the best time for the trial of causes, as ordained by the sacred code. IT

"After the first four hours (ghat'ticá), for that time is allotted to the business of the perpetual fire, and other religious affairs. In this space of three [eighth] parts of a day, the ling should constantly inspect law-suits.**

" ' The eighth part,' from the first half watch (prahara) to the second (prahara). +十

"The trial of causes, during the forenoon only, is here ordained. That again is intended for temporal purposes, because the understanding is then clear, and the king is yet disengaged from other business. A restriction is subjoined. The eighth part is half the first prahara: three parts subsequent thereto, but preceding the turn of noon: for else it would contradict the injunction for hearing causes in the forenoon. The omission of half the first prahara, too, is intended for a sensible purpose; as it serves to obviate any obstruction to the performance of daily sacrifices and the like.tf

"A wise man should not inspect judicial proceedings on these lunar days; namely, the fourteenth of each half of the month; the day of conjunction (new moon); that of opposition (full moon); and the eighth day of every semilunation. $\oint \oint$

"This prohibition is intended for spiritual ends, since it can have no temporal une: just like the prohibition of sitting towards a certain quarter [the south] during meal. :"

\footnotetext{
* Mádhava. +Dév. Bh. \$ Sim. Chand. \$ Mcome, T. 1+5.

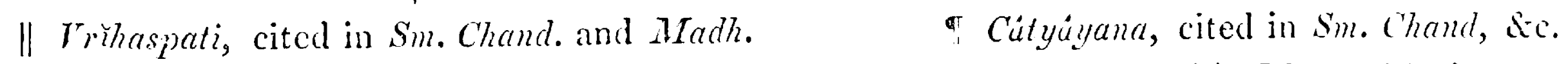

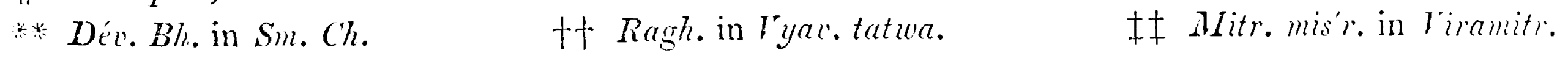

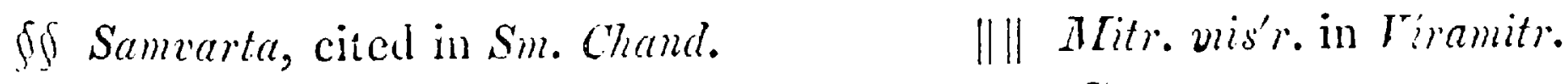

$2 \mathrm{C} 2$ 
"Let the king sit facing the east, and the judges facing the north; the accountant looking towards the west, and the scribe towards the south: and the king should cause gold, fire, water, and the code of law, to be placed in the midst of them, and also other holy things.*

"The rest may sit as most convenient; since there is no restriction concerning their places." + 